\title{
PENERAPAN TEKNOLOGI MODIFIKASI CUACA (TMC) UNTUK MENGATASI DEFISIT INFLOW PLTA BAKARU PERIODE 15 FEBRUARI SD. 03 MARET 2012
}

\author{
Djazim Syaifullah
}

\begin{abstract}
Weather modification technology have been conducted in the Mamasa watershed West Sulawesi to address the deficit inflow at Bakaru Hydroelectric power plant. During the implementation of these activities the cloudiness condition in the Mamasa watershed indicated the presence of fluctuations opportunities the existence of potential clouds. In general the potential clouds is quite good enough from the beginning to the end of the activity. In early activity, cloud growth relatively happening at noon and afternoon especially was in the mamasa and sumarorong, while in the end the weather conditions occurring with cloud growth fast enough and more found clouds potential. Indicating the number of inflow during the evaluation of this event is worth 100,60 million cubic meter with an average inflow of $64,68 \mathrm{~m} / \mathrm{second}$ in addition to inflow 16.77 million cubic meter. In general the implementation of Weather Modification Technology in in the Mamasa watershed has had suceeded in increasing inflow significantly
\end{abstract}

\section{Intisari}

Teknologi Modifikasi Cuaca (TMC) telah dilakukan di DAS Mamasa Sulawesi Barat untuk mengatasi defisit inflow PLTA Bakaru. Selama pelaksanaan kegiatan ini, kondisi perawanan di DAS Mamasa menunjukan adanya fluktuasi peluang keberadaan awan-awan potensial. Potensi awan secara umum cukup baik sejak awal sampai akhir kegiatan. Pada awal kegiatan, pertumbuhan awan relatif terjadi pada siang dan sore hari terutama terjadi di wilayah Mamasa dan Sumarorong, sementara di akhir kegiatan kondisi cuaca terjadi dengan pertumbuhan awan yang cukup cepat dan lebih banyak ditemukan awan potensial. Hasil evaluasi menunjukkan jumlah inflow selama kegiatan ini adalah sebesar 100,60 juta $\mathrm{m}^{3}$ dan rata-rata inflow sebesar $64,68 \mathrm{~m}^{3} /$ detik, dengan tambahan inflow hasil TMC sebesar 16.77 juta $\mathrm{m}^{3}$. Secara umum pelaksanaan Teknologi Modifikasi Cuaca di DAS Mamasa telah berhasil meningkatkan inflow secara signifikan.

Kata kunci : Teknologi Modifikasi cuaca, defisit inflow, PLTA Bakaru

\section{PENDAHULUAN}

Pembangkit Listrik Tenaga Air (PLTA) Bakaru merupakan salah satu pemasok energi listrik yang mempunyai peran strategis untuk wilayah Sulawesi Selatan, Sulawesi Tenggara dan Sulawesi Barat (Sulselrabar). PLTA Bakaru memanfaatkan potensi sumber daya air dari Daerah Aliran Sungai (DAS) Mamasa. Kapasitas produksi PLTA Bakaru sejak pertengahan Januari 2012 sudah mulai menurun dari kapasitas normal sebesar 126 MW. Ini disebabkan karena inflow yang tersedia pada periode tersebut berkisar di bawah $40 \mathrm{~m}^{3} /$ detik, dari yang seharusnya sekitar $43,5 \mathrm{~m}^{3} /$ detik yang

\footnotetext{
${ }_{1}^{1}$ Peneliti Madya - UPT Hujan Buatan, BPPT, Thamrin No. 8 Jakarta, email: djazimsy@yahoo.com
}

dibutuhkan untuk produksi listrik beban maksimum. Meskipun secara klimatologis di wilayah DAS Mamasa masih dalam periode musim hujan, kondisi ini ternyata terus berlanjut sampai dengan awal bulan Februari 2012. Atas dasar permasalahan tersebut, pihak PLN Wilayah Wilayah Sulawesi Selatan, Sulawesi Tenggara dan Sulawesi Barat (Sulselrabar) meminta UPT Hujan Buatan BPPT untuk melaksanakan kegiatan Teknologi Modifikasi Cuaca (Hujan Buatan) di wilayah DAS Mamasa, guna meningkatkan debit sungai Mamasa supaya produksi listrik PLTA Bakaru dapat kembali normal.

Permintaan pelaksanaan pekerjaan Teknologi Modifikasi Cuaca (TMC) dilakukan oleh PT PLN (Persero) Sulselrabar kepada UPT Hujan Buatan BPPT. Setelah melakukan beberapa tahap 


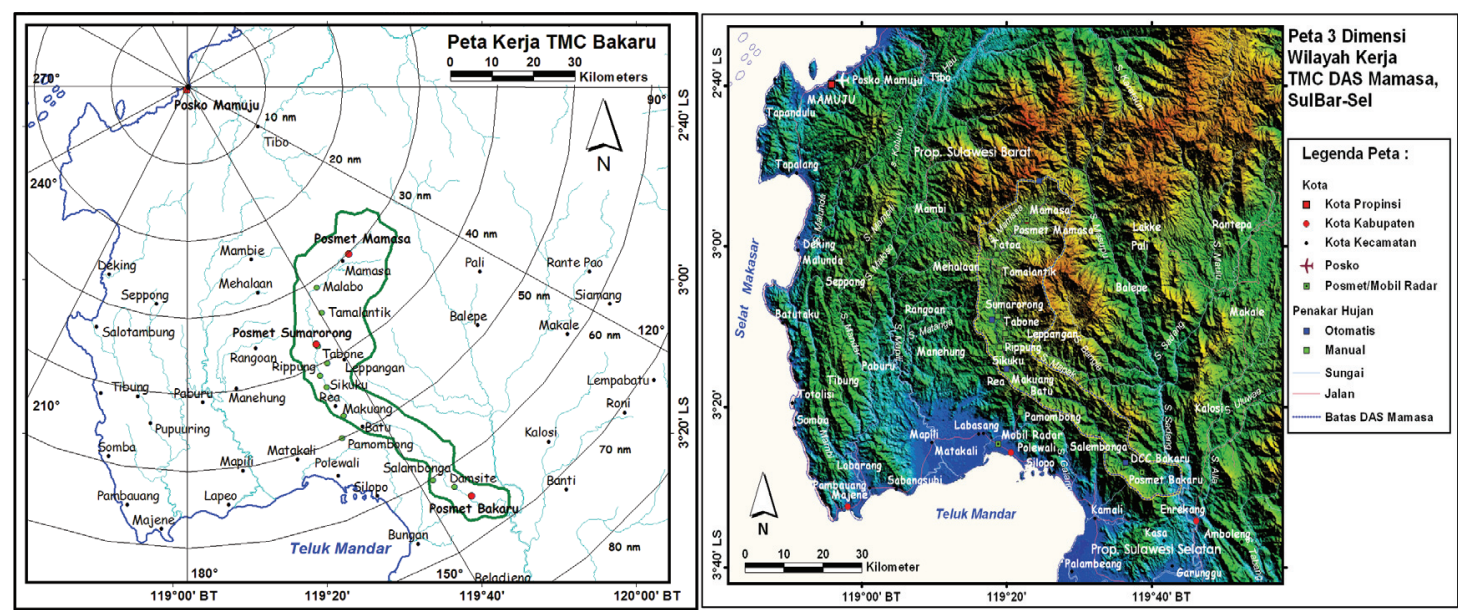

Gambar 1. Peta Wilayah Kerja TMC di DAS Mamasa dan penampakan 3D

persiapan dan koordinasi dengan berbagai instansi terkait, UPT Hujan Buatan selaku pihak pelaksana pekerjaan melaksanakan kegiatan TMC di DAS Mamasa mulai tanggal 15 Februari s.d. 03 Maret 2012 selama 17 (tujuh belas) hari pekerjaan.

Tujuan dari pelaksanaan penerapan TMC di DAS Mamasa ditujukan untuk mengatasi defisit inflow di PLTA Bakaru supaya PLTA tetap dapat berproduksi secara optimal.

\subsection{Daerah Kerja}

Daerah sasaran (target operasi) adalah seluruh wilayah DAS Mamasa, seperti yang tergambarkan dalam Gambar 1. Karakteristik fisik DAS Mamasa (dengan luas sekitar $1.080 \mathrm{~km}^{2}$ ) yang berbentuk pipih dengan topografi yang curam, serta sistem PLTA Bakaru yang memanfaatkan sistem run-off river (tanpa ada reservoir), menjadi suatu tantangan bagi UPT Hujan Buatan BPPT karena memiliki tingkat kesulitan yang cukup tinggi. Sistem run-off river ini menyebabkan curah hujan yang jatuh di dalam DAS Mamasa langsung dipergunakan untuk pembangkit listrik tanpa disimpan terlebih dahulu sebagai cadangan.

\subsection{Kondisi meteorologis daerah target}

\subsubsection{Analisis Cuaca Global}

Kondisi cuaca selama kegiatan pelaksanaan Teknologi Modifikasi Cuaca (TMC) dari tanggal 15 Februari hingga 03 Maret 2012 di wilayah DAS Mamasa dipengaruhi oleh kondisi cuaca global/ regional dan lokal. Kondisi cuaca global yang dominan pengaruhnya selama periode kegiatan adalah adanya; La Niña lemah, dominasi angin timuran dan pengaruh MJO.

La Niña merupakan suatu kondisi dimasa suhu muka laut di wilayah Indonesia lebih hangat daripada suhu muka laut pasifik timur (Gambar 2).
Nilai anomalinya antara $+0.5^{\circ} \mathrm{C}$ sampai $+1^{\circ} \mathrm{C}$. Pada kodisi ini pengangkatan massa uap air melalui proses konveksi cenderung terjadi di wilayah Indonesia. Akibat dari konveksi ini maka tekanan udara permukaan di wilayah Indonesia akan lebih rendah daripada tekanan udara di pasifik. Sehingga massa udara (yang banyak mengandung uap air) akan bergerak dari samudera pasifik (tekanan tinggi) ke wilayah Indonesia (tekanan rendah). Kawasan Indonesia timur merupakan daerah yang menerima efek yang besar dari fenomena ENSO ini. Sehingga pada kondisi La Niña ini pertumbuhan awan akan lebih mudah terjadi.

La Niña lemah dapat memberikan supply awan-awan yang potensial di daerah target, dimana kondisi cukup menguntungkan pelaksanaan TMC di DAS Mamasa. Angin timuran masih terlihat mendominasi di wilayah target, dimana kondisi ini menunjukkan masih banyak uap air dari samudera pasifik untuk pertumbuhan awan. Selain itu, osilasi harian (diurnal oscillation) cukup kuat pengaruhnya terhadap daerah target sehingga pembentukan awan pada sore hari berlangsung baik. Topografi daerah target yang bergunung-gunung juga mendukung terjadinya awan-awan orografis.

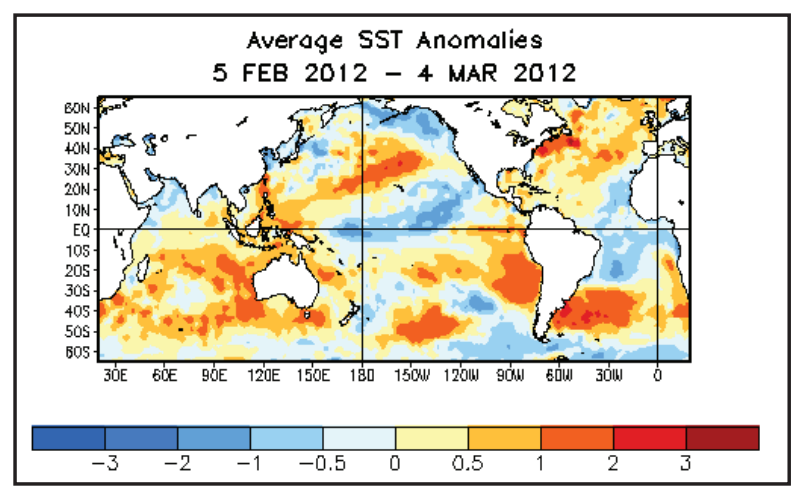

Gambar 2. Peta anomali suhu muka laut rerata selama 5 Februari - 4 Maret 2012. (diambil dari ENSO Cycle: Recent Evolution, Current Status and Predictions - edisi Maret 2012). 
Menurut ENSO Cycle: Recent Evolution, Current Status and Predictions - edisi Maret 2012 yang diterbitkan oleh Climate Prediction Center, La Niña lemah sedang terjadi dan semakin melemah hingga bulan Maret 2012 (mendekati pada kondisi netral).

MJO (Madden Julian Oscillation) merupakan fenomena global berupa gelombang atmosfer di sekitar equator yang bergerak ke arah timur. MJO mempunyai periode yang bervariasi sekitar $40-50$ hari. Fase dari gelombang ini disebut fase aktif dan fase inaktif. Fase aktif diasosiasikan dengan nilai negatif dari outgoing longwave radiation (OLR) yang merupakan radiasi balik gelombang panjang dari planet bumi ke luar sistem atmosfer bumi akibat radiasi matahari yang masuk. Radiasi gelombang panjang tersebut diserap oleh awan tebal sehingga radiasi yang keluar dari sistem atmosfer bumi menjadi negatif, sehingga nilai negative mengindikasikan banyaknya pertumbuhan awan. Demikian sebaliknya fase inaktif diasosiasikan dengan nilai positif OLR.

Gambar 3. berikut memperlihatkan plot Bujur - Waktu OLR di daerah tropis yang memperlihatkan kondisi MJO aktif sejak Dasarian II Februari 2012 di posisi $40^{\circ} \mathrm{BT}$ dan bergerak ke arah timur dan mencapai daerah target di posisi $120^{\circ} \mathrm{BT}$ pada Dasarian I Maret 2012. Dengan masuknya sistem keawanan yang berasosiasi dengan MJO menunjukkan fase aktif di Samudera Hindia dan juga adanya pertumbuhan awan konvektif sangat besar dari barat Indonesia dapat membantu pertumbuhan awan yang baik di daerah target sampai pertengahan Maret.

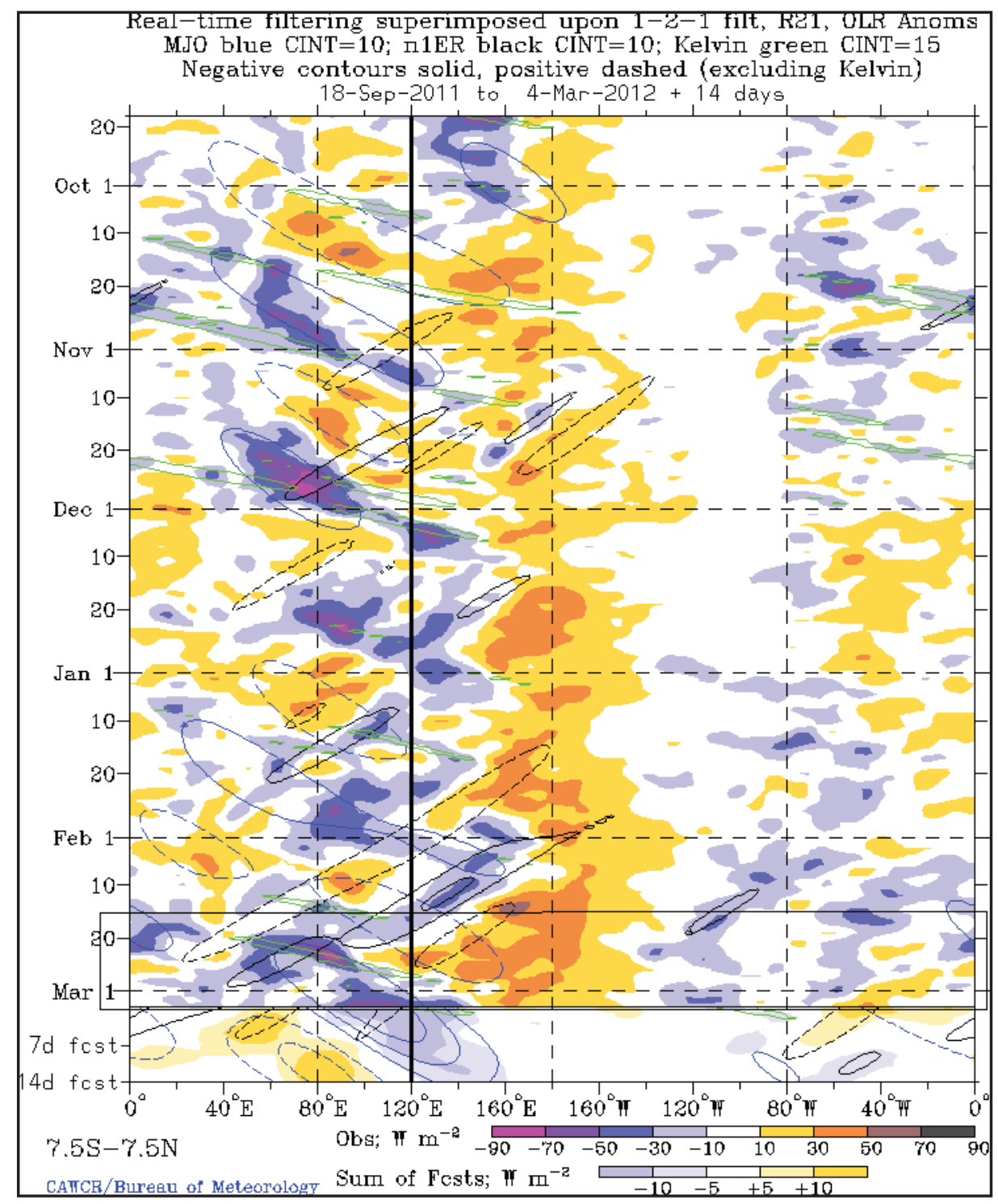

Gambar 3. Plot bujur-waktu OLR rata-rata 7,5 LS - 7,5 LU. Positif anomali (warna kuning) diasosiasikan dengan kurang menunjang presipitasi, sementara anomali negatif (warna biru) diasosiasikan dengan sangat mendukung pembentukan presipitasi. Daerah target terletak pada bujur $120 \mathrm{oBT}$ (garis tebal tegak) 
Gradient wind adalah angin yang terbentuk karena adanya perbedaan tekanan pada dua titik yang biasanya diamati pada level ketinggian (paras) 3000 feet (sekitar 1000 meter) di atas permukaan laut yang menggambarkan aliran udara pada atmosfer bagian bawah dimana tidak lagi terpengaruh oleh adanya gesekan permukaan bumi. Pada level ini tidak ada pengaruh angin lokal maupun pengaruh topografi seperti angin laut, angin darat, angin lembah dan sebagainya.

Angin gradien di daerah target dan sekitarnya umumnya bertiup dari arah timur dengan kecepatan berkisar antara $15-20$ knots, seperti terlihat pada gambar 4. Pusaran angin (Eddy) dan pusat tekanan rendah yang muncul di barat Sumatera semakin memperkuat angin timuran yang mendukung terjadinya pembentukan awan di wilayah target.

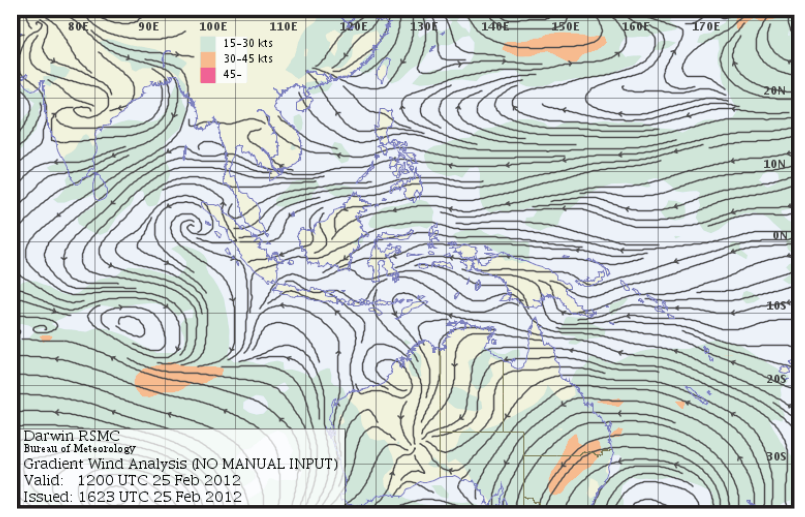

Gambar 4. Angin gradien lapisan 3000 feet tanggal 25 Februari 2012 jam 07.00 WITA (Bureau of Meteorology, Australia).

Citra satelit digunakan sebagai informasi tutupan dan jenis awan di atmosfer. Citra satelit yang digunakan untuk analisis dalam kegiatan penerapan TMC di DAS Mamasa diambil dari chanel / kanal infra merah. Sensor infra merah satelit mendeteksi obyek berdasarkan suhu obyek dan dikonversikan ke dalam gradasi warna. Semakin dingin suhunya, warna objek semakin putih. Sebaliknya semakin panas suhunya, warna objek semakin hitam. Gambar 5. berikut adalah contoh citra satelit yang diambil dari Bureau of Meteorology Australia.

Pergerakan awan dapat diamati dengan menggunakan citra satelit secara realtime setiap jam. Dari citra satelit pada Februari - Maret 2012 terlihat bahwa sistem keawanan regional yang direpresentasikan oleh MJO fase aktif telah masuk ke wilayah Indonesia sehingga di daerah target mendapat supply uap air yang membantu pertumbuhan awan.

\subsubsection{Analisis Cuaca Lokal}

Potensi cuaca lokal dianalisa menggunakan data cuaca permukaan yang diperoleh dari pengamatan pos meteorologi (Posmet) yang berada di Mamasa, Sumarorong dan Bakaru.

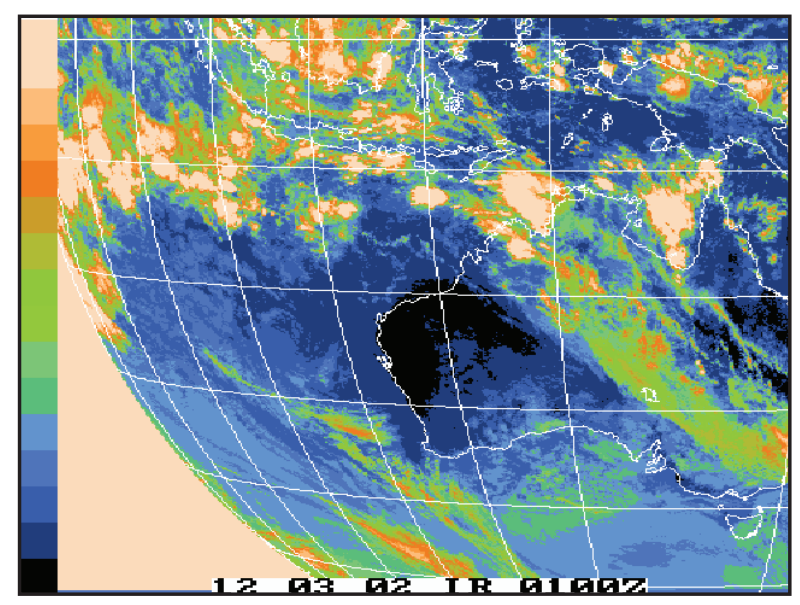

Gambar 5. Citra satelit tanggal 02 Maret 2012 jam 09.00 WITA (Bureau of Meteorology Australia).

Data cuaca permukaan yang diukur terdiri dari: tekanan udara permukaan $(\mathrm{P})$; temperatur bola basah (BB) dan bola kering (BK atau $\mathrm{T}$ ); untuk mendapatkan nilai kelembaban udara $(\mathrm{RH})$; temperatur titik embun (Td). Pengukuran pilot balon (Pibal) digunakan untuk mengukur arah dan kecepatan angin atas secara vertikal. Selain mengukurcuaca permukaan dan anginatas, Posmet digunakan untuk memonitor perkembangan awan potensial serta suplai massa udara yang masuk ke daerah target secara visual. Pengukuran cuaca permukaan dilakukan setiap jam dari jam 07.00 s.d. 17.00 WITA, sedangkan angin atas diukur setiap 3 jam sekali yaitu jam 07.00, 10.00, 13.00 dan 16.00 WITA. Data hasil pengukuran dan pengamatan langsung dikirim ke Posko untuk dianalisis. Data cuaca permukaan dan angin atas hasil pengukuran ini dianalisis untuk menilai kecenderungan potensi cuaca setiap hari sehingga menjadi bahan masukan dalam pelaksanaan TMC.

Selama kegiatan kisaran suhu udara tersebut umumnya bervariasi untuk semua stasiun pengamatan, namun secara umum memiliki perbedaan $>40 \mathrm{C}$ antara pagi hari (pukul 07.00 WITA) dengan pukul 10.00 WITA. Nilai ini menunjukkan adanya radiasi yang masuk ke permukaan sehingga terjadi kenaikan suhu permukaan. Peningkatan suhu ini mengindikasikan potensi terjadinya proses konvektif. 
Disamping kondisi cuaca lokal permukaan, juga dianalisis kondisi angin atas yang bersifat lokal yang diambil dari pengukuran pibal. Analisis angin atas ini dilakukan untuk melihat perkembangan pola angin lokal yang terbentuk. Dari analisis angin ini tampak bahwa pola angin umumnya bervariasi antara berhimpit (confluent) dan divergen. Pada daerah target angin umumnya menunjukkan variasi arah angin di setiap level ketinggian. Angin bertiup dari timur di lapisan bawah hingga utara di lapisan atas. Kecepatan angin bervariasi antara $5-20$ knot.

\subsubsection{Analisis Radar C-Band}

Informasi perawanan yang sangat vital bagi jalannya pekerjaan ini salah satunya adalah data radar cuaca jenis C-band milik Badan Meteorologi, Klimatologi dan Geofisika (BMKG) Propinsi Sulawesi Selatan yang dioperasikan di Makasar. Data ini memberikan gambaran tentang obyek awan yang meliputi ketinggian dasar awan, puncak awan dan diameter awan serta tingkat reflektivitas awan yang menggambarkan tingkat kandungan air dalam awan. Radar ini dapat menjangkau daerah target yang jaraknya sekitar $150-250$ kilometer. Hasil analisisnya digunakan untuk memonitor perkembangan pertumbuhan awan di DAS Mamasa. Informasi data radar ini juga digunakan untuk memonitor perkembangan awan setelah proses penyemaian awan, dengan mamantau awan sebelum penyemaian, selama penyemaian dan setelah penyemaian. Gambar 6. menunjukkan contoh pantauan radar cuaca selama pelaksanaan penyemaian.

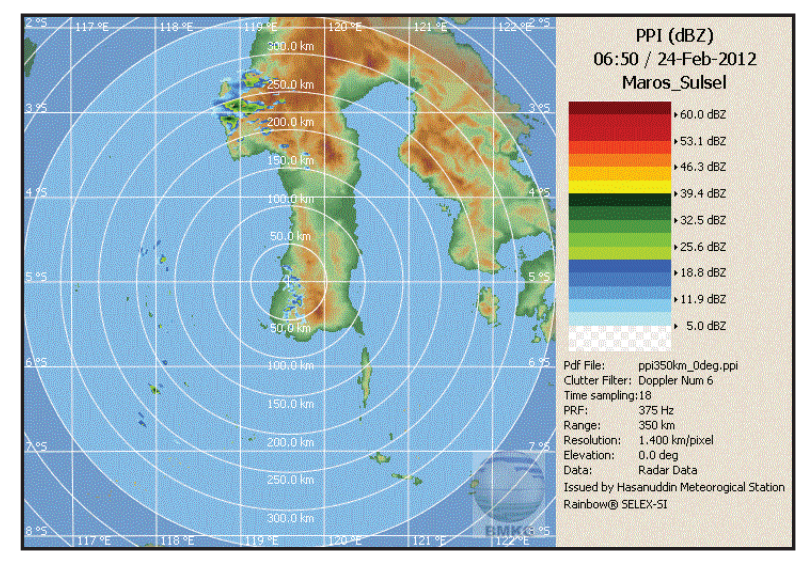

Gambar 6. Pantauan radar cuaca pada tanggal 24 Februari 2012 jam 14.50 WITA.

Dari pemantauan radar cuaca, awan yang tumbuh di daerah target pada umumnya mulai terjadi pada siang hingga sore hari. Faktor lokal seperti angin laut (sea breaze) cukup berpengaruh terhadap pertumbuhan awan di daerah target. Angin laut yang berhembus mulai siang hingga sore hari mengakibatkan uap air naik ke atmosfer akibat tertahan oleh pegunungan yang ada di sekitar DAS Mamasa. Uap air tersebut akhirnya membentuk awan-awan orografik di sebagian besar batas DAS bagian barat dan selatan seperti di daerah Sumarorong dan Makuang.

Secara umum dapat disimpulkan bahwa kondisi cuaca di DAS Mamasa dipengaruhi oleh gabungan dari berbagai faktor meteorologi yang seperti fenomena El Niño , MJO, Gelombang ekuatorial Rossby, pusat tekanan rendah, dan faktor topografi lokal. La Niña memberikan supply uap air dari wilayah Samudera Pasifik bagian barat sehingga banyak membantu pembentukan awan selama kegiatan. MJO fase aktif yang bergerak dari Samudera Hindia di awal kegiatan menuju wilayah Indonesia bagian timur mendukung pada akhir Februari. Topografi daerah target yang bergununggunung menjadi faktor yang memungkinkan bagi pembentukan awan, meskipun ada beberapa kondisi meteorologis lainnya yang menghambat.

\section{PELAKSANAAN KEGIATAN}

Mengingat pertumbuhan awan di wilayah daerah target relatif lambat, maka penerbangan sorti pertama direncanakan sekitar jam 13.00 - 14.30 WITA dan penerbangan sorti kedua direncanakan sekitar jam 15.00 - 16.00 WITA. Direncanakan 2 (dua) sorti setiap hari, namun realisasinya tergantung kondisi cuaca yang setiap saat selalu berubah.

Kegiatan penerbangan penyemaian awan dipandu oleh flight Scientist, yang mempunyai kemampuan dalam menganalisis kondisi awan dan dapat memutuskan apa yang harus dilakukan selama penerbangan. Selain harus mempunyai pengetahuan dasar meteorologi, seorang flight scientist mempunyai kemampuan khusus diantaranya : mampu mengamati ada tidaknya awan potensial dan memilih awan yang layak disemai berdasarkan kriteria yang telah ditentukan, mampu membaca dan memantau instrumen pesawat dan mentransformasikannya ke dalam peta serta mampu mengoperasikan peralatan Global Positioning System (GPS).

Pengoperasian GPS dimaksudkan untuk melihat tracking pesawat mulai onboard, selama penerbangan dan saat penyemaian awan, hingga pesawat kembali ke Posko, sehingga route dan manuver pesawat selama terbang terekam dengan baik. Pengoperasian GPS dilakukan oleh Flight Scientist selama penerbangan eksekusi. 
Penerbangan di luar daerah target dilakukan dengan mempertimbangkan arah angin agar awan yang disemai masuk ke daerah target saat menjadi hujan. Berikut rekapitulasi tracking pesawat Casa 212-200 ke daerah target selama periode kegiatan dapat dilihat pada Gambar 7.

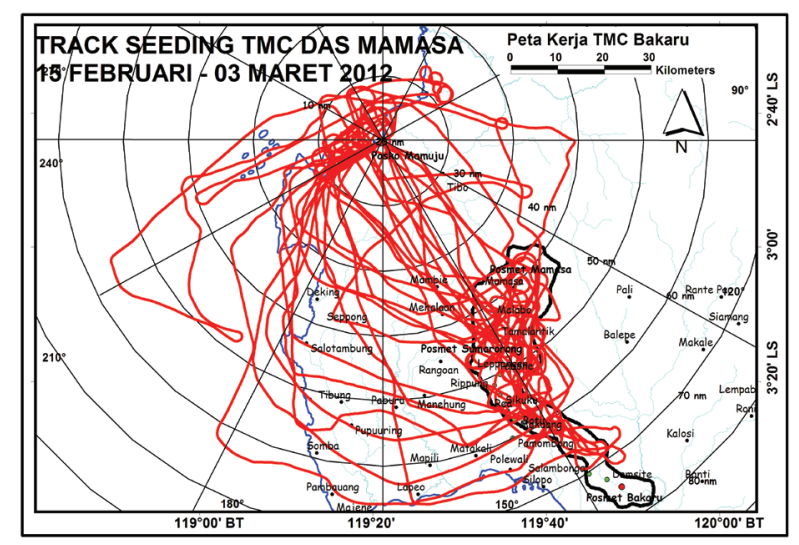

Gambar 7. Rekapitulasi track penyemaian selama periode kegiatan tanggal 15 Februari sd. 03 Maret 2012.

Gambar 8. di bawah ini merupakan contoh pemantauan radar sebelum dilakukan penyemaian dan setelah dilakukan penyemaian beserta track penerbangannya. kondisi aliran aktual dan jumlah aliran inflow selama kegiatan TMC. Data hidrologi yang dimonitor setiap hari adalah curah hujan, inflow outflow selama kegiatan TMC berlangsung.

\subsection{Informasi Kejadian Hujan}

Informasi kejadian hujan diperoleh dari beberapa sumber yaitu : laporan dari flight Scientist yang baru menyelesaikan penerbangan, laporan Petugas Observer Cuaca BPPT di Posmet Mamasa, Posmet Sumarorong, Posmet Bakaru, serta laporan dari pengamat curah hujan di masing - masing lokasi dimana terpasang peralatan penakar curah hujan manual. Total penakar curah hujan yang terpasang di daerah target berjumlah 13; 12 lokasi berada di dalam DAS Mamasa dan 1 lokasi berada di luar DAS Mamasa sebagai daerah kontrol.

Informasi kejadian hujan secara kuantitatif dapat dilihat pada Gambar 9. Selama periode kegiatan TMC tanggal 15 Februari - 03 Maret 2012, setiap harinya selalu turun hujan di dalam daerah target dengan intensitas hujan yang beragam seperti terlihat pada Gambar 9.

\subsection{Distribusi Curah Hujan.}

Selama periode kegiatan TMC tanggal 15

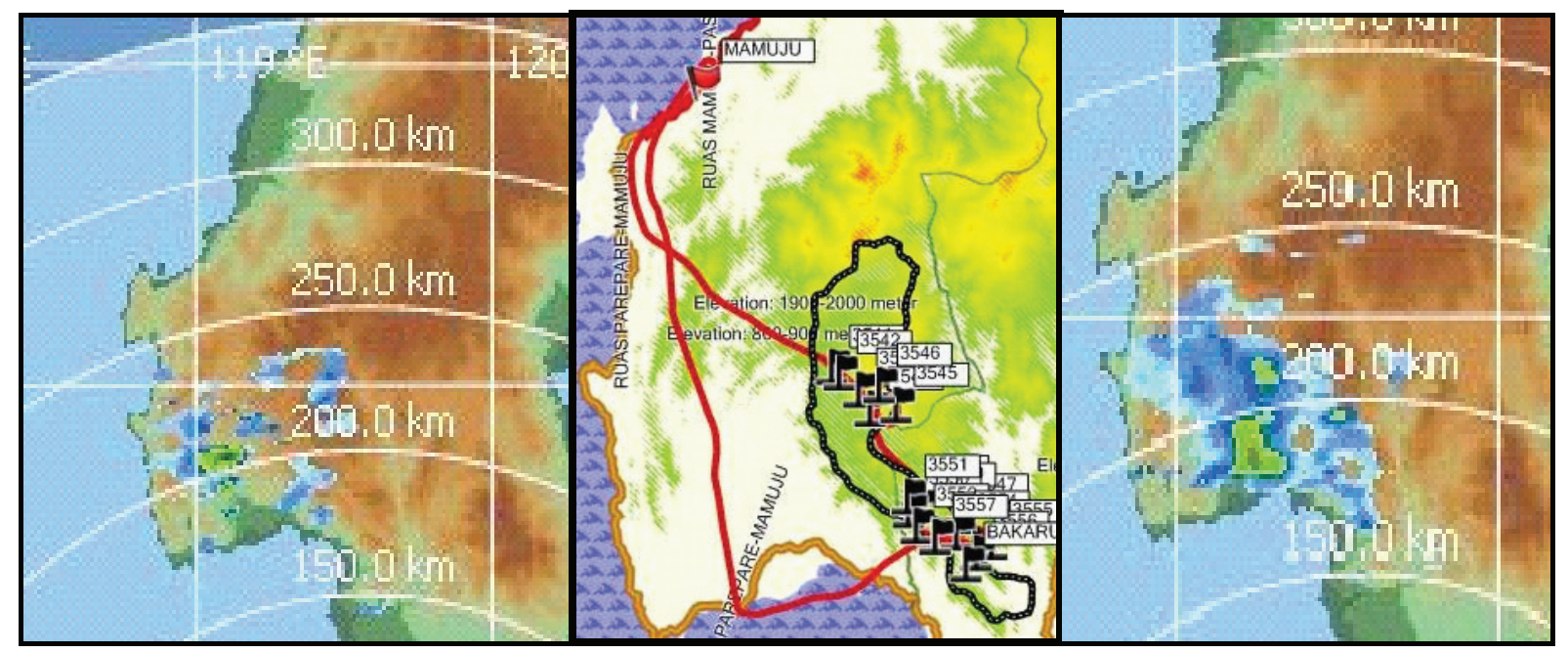

Gambar 8. Citra radar sebelum penerbangan (kiri), Peta Penerbangan tanggal 15 Februari 2012 (tengah) dan citra radar setelah penerbangan (kanan)

\section{HASIL DAN PEMBAHASAN}

Hasil kegiatan meliputi informasi kejadian hujan, informasi distribusi curah hujan, informasi durasi curah hujan, informasi intensitas curah hujan dan informasi aliran di daerah target serta kondisi hidrologi DAS Mamasa yang dipantau di Dam Site (DCC) Bakaru. Informasi aliran berupa
Februari - 03 Maret 2012, setiap harinya selalu terjadi hujan dengan distribusi yang hampir merata di daerah target dengan intensitas yang berbeda. Di bagian utara (Mamasa, Malabo dan Talamantik) hingga bagian tengah DAS Mamasa (Sumarorong, Tabone, Ripung, Sikuku dan Makuang) hujan terjadi setiap hari, sementara di bagian Selatan DAS Mamasa (Salembongan dan Bakaru) sempat 


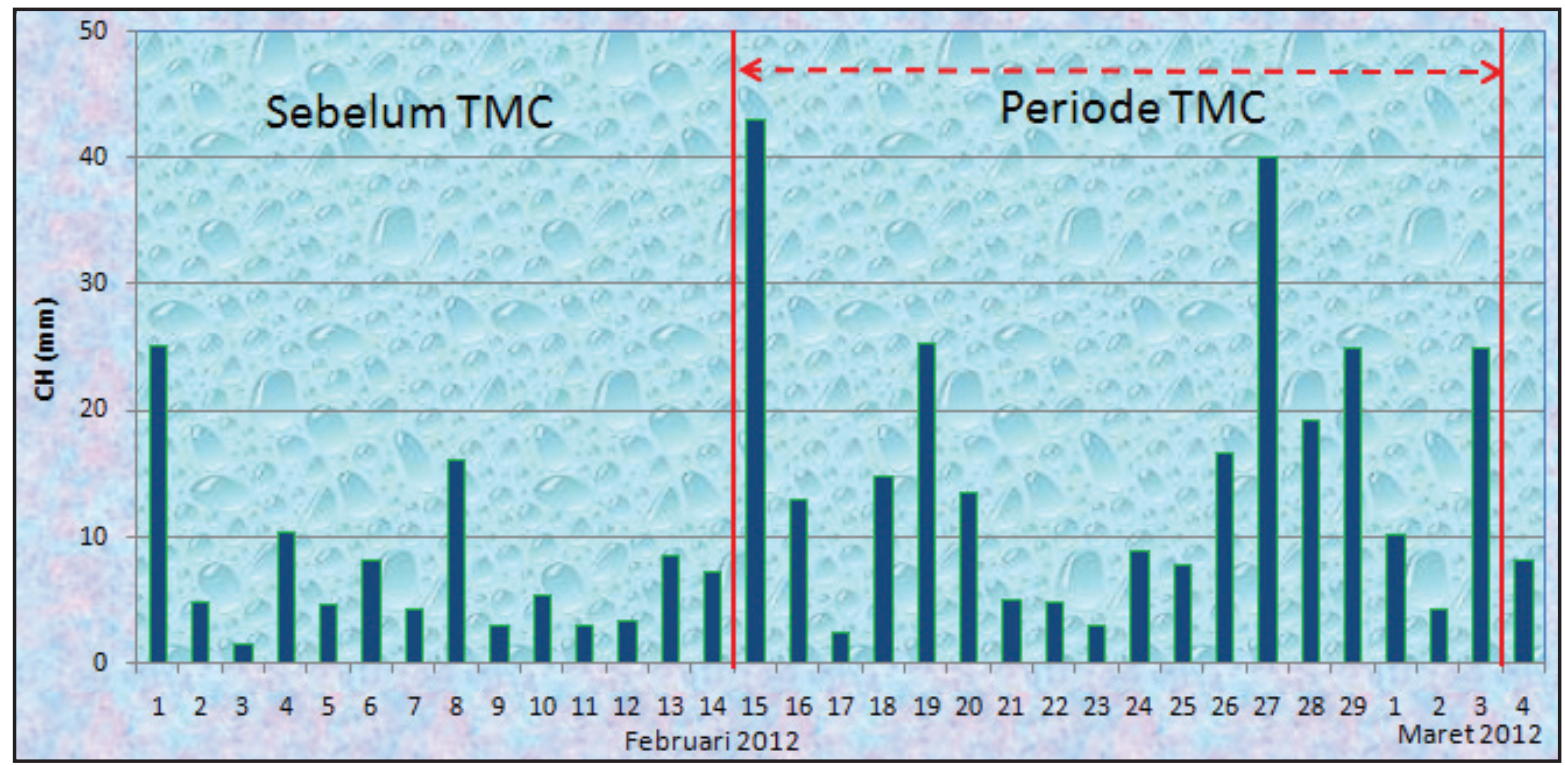

Gambar 9. Grafik rata-rata curah hujan wilayah DAS Mamasa selama Kegiatan TMC periode 15 Februari sampai dengan 03 Maret 2012

tidak terjadi hujan pada tanggal 21, 23, 28 Februari dan 01 Maret 2012.

Untuk análisis, data curah hujan yang digunakan berasal dari 12 (dua belas) lokasi stasiun penakar hujan milik BPPT yang terpasang di dalam DAS Mamasa selama kegiatan TMC berlangsung. Kedua belas lokasi penakar hujan tersebut adalah di Posmet Mamasa, Posmet Bakaru, Posmet Sumarorong, DCC Bakaru, Salembongan, Pamombong, Makuang, Rippung, Sumarorong, Tamalantik, Malabo dan Tabone. Sementara untuk daerah kontrol dipasang satu buah penakar di luar DAS Mamasa, yaitu di Pamombong yang berada di sebelah Barat Daya DAS Mamasa.

Akumulasi curah hujan wilayah DAS Mamasa selama periode kegiatan TMC adalah sebesar $281,1 \mathrm{~mm}$ dengan nilai rerata hariannya sebesar $15,6 \mathrm{~mm} / \mathrm{hari}$. Curah hujan tertinggi berada di Sumarorong $(460 \mathrm{~mm})$ sementara yang terendah berada di Malabo (157,5 mm).

Dari Gambar 10 terlihat bahwa curah hujan di DAS Mamasa selama periode 15 Februari 03 Maret 2012 paling banyak terjadi pada bagian tengah DAS (Sumarorong dan sekitarnya ke arah selatan). Pada wilayah ini, total curah hujannya di atas $300 \mathrm{~mm}$. Daerah hulu DAS (utara) yang diwakili oleh stasiun Posmet Mamasa dan Stasiun Malabo serta daerah hilir DAS (selatan) yang diwakili stasiun Posmet Bakaru dan penakar di DCC Bakaru curah hujannya cenderung lebih kecil, yaitu kurang dari $200 \mathrm{~mm}$.

Distribusi curah hujan yang masih relatif cukup tinggi di wilayah tengah DAS Mamasa menyebabkan hujan yang terjadi pada hari itu masih dapat memberikan kontribusi aliran di damsite PLTA Bakaru dalam beberapa hari berikutnya.

\subsection{Durasi dan Intensitas Curah Hujan}

Data curah hujan yang digunakan dalam analisis intensitas curah hujan adalah jumlah curah hujan dalam satu hari, karena sebagian besar alat penakar hujan yang terpasang di lapangan masih menggunakan sistem manual.

Sejak awal kegiatan TMC dilakukan di DAS Mamasa, kondisi klimatologis mengindikasikan bahwa cuaca di wilayah target mulai basah dengan indikasi kondisi angin timuran yang membawa uap air dari Samudera Pasifik. Hal ini ditandai dengan durasi terjadinya hujan yang terjadi di beberapa stasiun penakar curah hujan yang berlangsung dalam durasi lama. Hujan secara umum berlangsung sekitar 1 (satu) hingga 2 (dua)

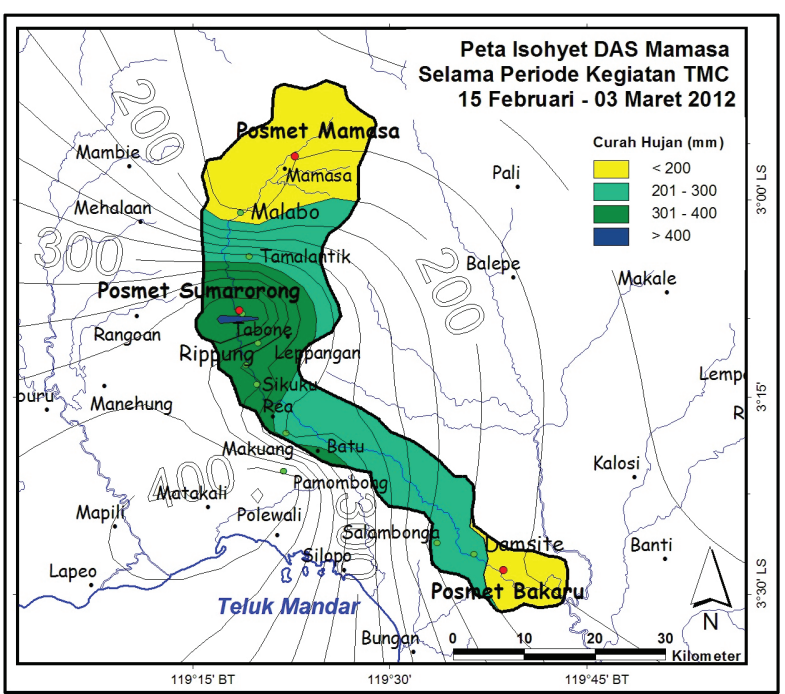

Gambar 10. Distribusi spasial curah hujan DAS Mamasa selama periode TMC (sumber : UPT Hujan Buatan) 
jam pada sore hari, bahkan di beberapa lokasi hujan terjadi dengan durasi yang cukup lama sejak sore hingga malam hari ataupun sejak malam hingga dini hari. Besarnya intensitas curah hujan yang terjadi di daerah target selama kegiatan TMC berlangsung mulai dari intensitas gerimis (tidak terukur), sedang sampai lebat.

Selama periode kegiatan TMC hujan terjadi secara merata di dalam DAS dengan intensitas cukup tinggi (>10 $\mathrm{mm} /$ hari) sebanyak 10 hari, yaitu pada tanggal 15, $1618,19,20,26,27,28$ dan 29 Februari 2012 serta 03 Maret 2012. Intensitas curah hujan harian tertinggi untuk wilayah DAS Mamasa terjadi pada hari pertama kegiatan, tanggal 15 Februari 2012 dengan intensitas hujan mencapai $43,1 \mathrm{~mm} /$ hari. Pada tanggal tersebut, di beberapa lokasi terjadi hujan dengan intensitas tinggi (diatas $50 \mathrm{~mm} / \mathrm{hari})$, yaitu di Sumarorong $(88 \mathrm{~mm})$, Posmet Sumarorong $(79,5 \mathrm{~mm})$, Tabone $(70,5 \mathrm{~mm})$ dan Salembongan $(54,5 \mathrm{~mm})$. Kejadian hujan dengan intensitas tinggi lainnya terjadi pada tanggal 27 Februari 2012, yaitu sebesar $40.1 \mathrm{~mm} /$ hari, dimana pada tanggal tersebut intensitas hujan yang tinggi terjadi di Sikuku (68.5 mm), Sumarorong $(68 \mathrm{~mm})$, Posmet Sumarorong $(56 \mathrm{~mm})$ dan Rippung (56 $\mathrm{mm})$.

Jumlah hari hujan terbanyak selama kegiatan TMC terjadi di Posmet Mamasa, Talamantik, Malabo, Posmet Sumarorong dan Sumarorong sebanyak 17 (tujuh belas) hari, sedangkan jumlah hari hujan paling sedikit berada di Salembongan dan DCC Bakaru, yaitu 14 (empat belas) hari.

\subsection{Informasi Aliran}

Informasi aliran menyangkut kondisi hidrologi waduk yang terdiri dari Tinggi Muka Air (TMA), Inflow ( $\left.\mathrm{m}^{3} / \mathrm{det}\right)$ dan Outflow $\left(\mathrm{m}^{3} /\right.$ det), yang terbagi menjadi discharge / pemakaian air $\left(\mathrm{m}^{3} /\right.$ detik) dan limpasan ( $\mathrm{m}^{3} /$ detik). Kondisi hidrologi di PLTA Bakaru berbeda dengan waduk-waduk lain di Indonesia yang difungsikan sebagai PLTA. Kondisi waduk di PLTA Bakaru hanya berfungsi untuk menaikkan tinggi muka air sungai kemudian disalurkan ke suatu saluran menuju turbin untuk keperluan PLTA. Karena fungsi bendung (dam) hanya menaikan tinggi muka air, maka bendung Bakaru tidak berfungsi sebagai penyimpan air (reservoir) layaknya waduk-waduk lain seperti Waduk Kotopanjang di Riau atau Waduk Cirata, Saguling dan Jatiluhur di Jawa Barat.

Karena Bendung Bakaru tidak mempunyai fungsi penyimpan air, maka jika terjadi aliran air yang besar akan terjadi limpasan diatas bendung dan airnya mengalir menuju laut, tanpa bisa dimanfaatkan lebih berdaya guna lagi.

Selama kegiatan TMC, nilai inflow yang terukur di DCC Bakaru menunjukkan nilai yang fluktuatif. Nilai rata-rata inflow sebesar $64,68 \mathrm{~m}^{3} /$ detik dan nilai inflow tertinggi terjadi pada tanggal 01 Maret 2012 sebesar 124,66 m³/detik yang menyebabkan limpasan sebesar $81,11 \mathrm{~m}^{3} /$ detik. Fluktuasi nilai inflow, discharge dan limpasan selama kegiatan TMC dapat dilihat pada Gambar 11 berikut ini.

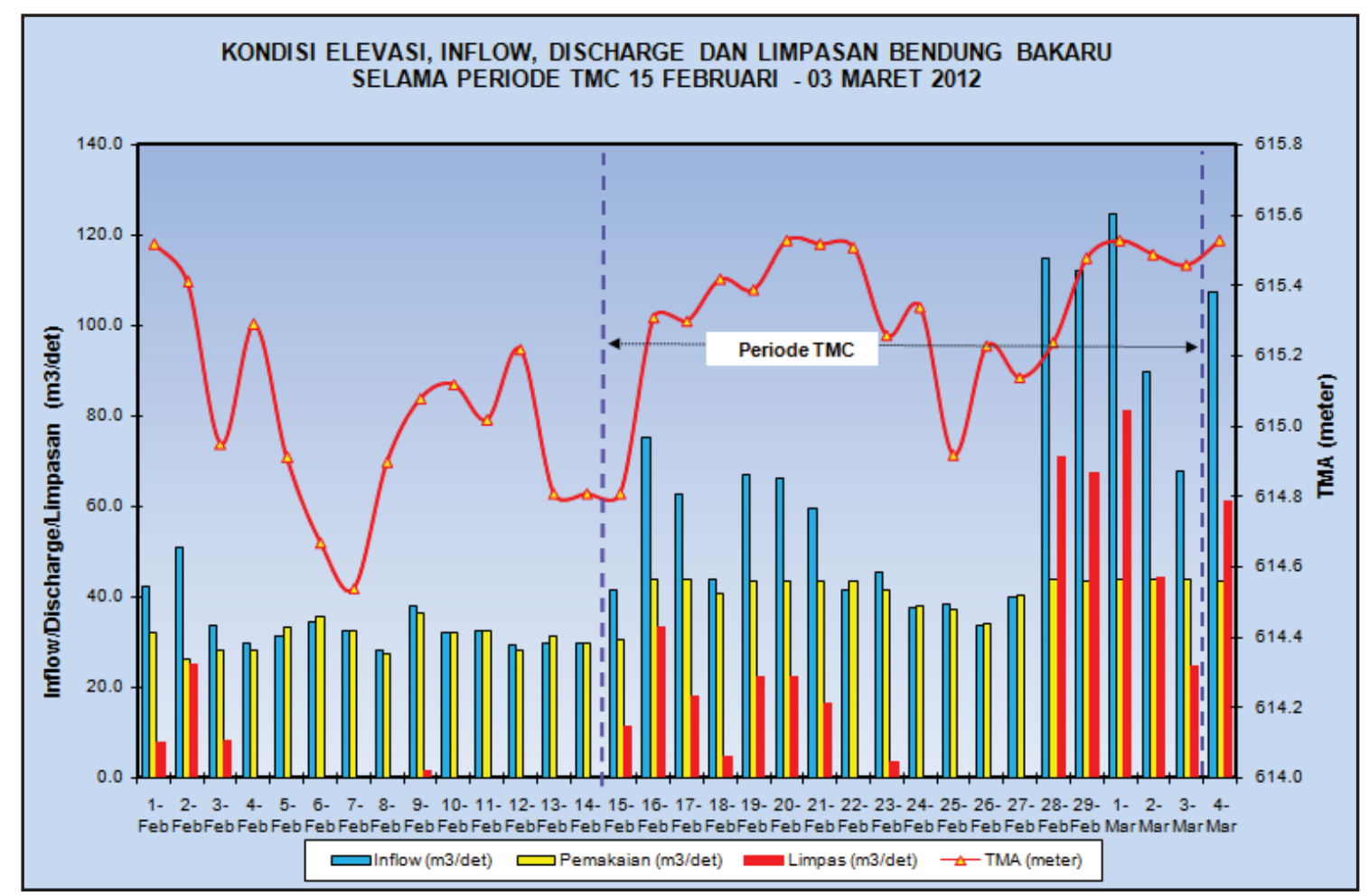

Gambar 11. Fluktuasi Inflow, discharge, limpasan dan tinggi muka air DCC Bakaru selama periode Kegiatan TMC 
Peningkatan inflow di Bendung Bakaru selama periode kegiatan TMC dapat dilihat pada Gambar 12 di bawah ini. Garis berwarna biru adalah nilai inflow historis dalam 27 tahun terakhir (tahun 1985 - 2011), garis berwarna hijau adalah inflow tahun 2011 dan garis berwarna ungu adalah inflow aktual tahun 2012. Dari Gambar 12 terlihat jelas bahwa secara umum kondisi inflow sejak awal tahun 2012 hingga sebelum dimulainya kegiatan TMC selalu berada di bawah nilai historis maupun kondisi tahun 2011 (kecuali beberapa hari di pertengahan Januari 2012). Semenjak dimulainya kegiatan TMC, kondisi inflow di Bendung Bakaru mengalami kenaikan secara signifikan. Pada periode awal kegiatan, kondisi inflownya melebihi nilai inflow tahun 2011 dan mulai mendekati nilai historisnya. Di periode pertengahan kegiatan, meski kondisi inflownya sempat menurun namun masih tetap berada di atas nilai tahun 2011, dan pada periode akhir kegiatan kondisi inflow aktual saat ini meningkat kembali bahkan jauh melebihi nilai tahun 2011 maupun nilai historisnya.

Dari profil inflow terlihat dengan jelas bahwa pelaksanaan Teknologi Modifikasi Cuaca di DAS Mamasa telah berhasil meningkatkn inflow secara signifikan.

Dengan mengambil asumsi dan berdasarkan pengalaman pelaksanaan TMC di Indonesia yang mampu menghasilkan tambahan air hujan sebanyak $20 \%$ sampai dengan $100 \%$, serta pernyataan dari World Meteorological Organization (WMO), bahwa kegiatan TMC mampu menghasilkan rata-rata kenaikan curah hujan berkisar $20 \%$, maka jumlah tambahan inflow yang terukur selama kegiatan TMC berlangsung adalah $20 \% \times(100,60 /(120 \%))$
$=16,77$ juta $\mathrm{m}^{3}$. Jumlah inflow yang terpakai setiap harinya untuk pemakaian produksi listrik adalah air yang keluar untuk menggerakkan turbin pembangkit listrik (discharge) sementara sisanya terbuang dalam bentuk limpas. Akumulasi pemakaian air selama kegiatan adalah 64,23 juta $\mathrm{m}^{3}$ sehingga tambahan inflow sebagai pemakaian air adalah $20 \% \times(64,23 /(120 \%))=10,70$ juta $\mathrm{m}^{3}$.

\section{KESIMPULAN}

Akumulasi curah hujan wilayah DAS Mamasa selama periode kegiatan TMC adalah sebesar $281,1 \mathrm{~mm}$ dengan nilai rerata hariannya sebesar $15,6 \mathrm{~mm} /$ hari. Curah hujan di DAS Mamasa paling banyak terjadi pada bagian tengah DAS. Daerah hulu serta daerah hilir DAS curah hujannya cenderung lebih kecil.

Berdasarkan perhitungan Tim Evaluasi UPTHB BPPT, besarnya aliran hasil kegiatan TMC yang masuk di daerah target selama kegiatan TMC tanggal 15 Februari sd. 03 Maret 2012 adalah sebesar 100,60 juta $\mathrm{m}^{3}$, dengan inflow rata-rata sebesar $64,68 \mathrm{~m}^{3} /$ detik. Dengan mengambil asumsi bahwa kegiatan TMC mampu menghasilkan kenaikan rata-rata inflow berkisar 20\%, maka jumlah tambahan inflow yang diperoleh selama kegiatan TMC berlangsung adalah sekitar 16,77 juta $\mathrm{m}^{3}$.

Hasil lain dari pekerjaan TMC adalah meningkatnya curah hujan yang bermanfaat bagi masyarakat di DAS Mamasa dan wilayah hilir sungai Mamasa untuk berbagai keperluan. Pelaksanaan Teknologi Modifikasi Cuaca di DAS Mamasa telah berhasil meningkatkn inflow secara signifikan.

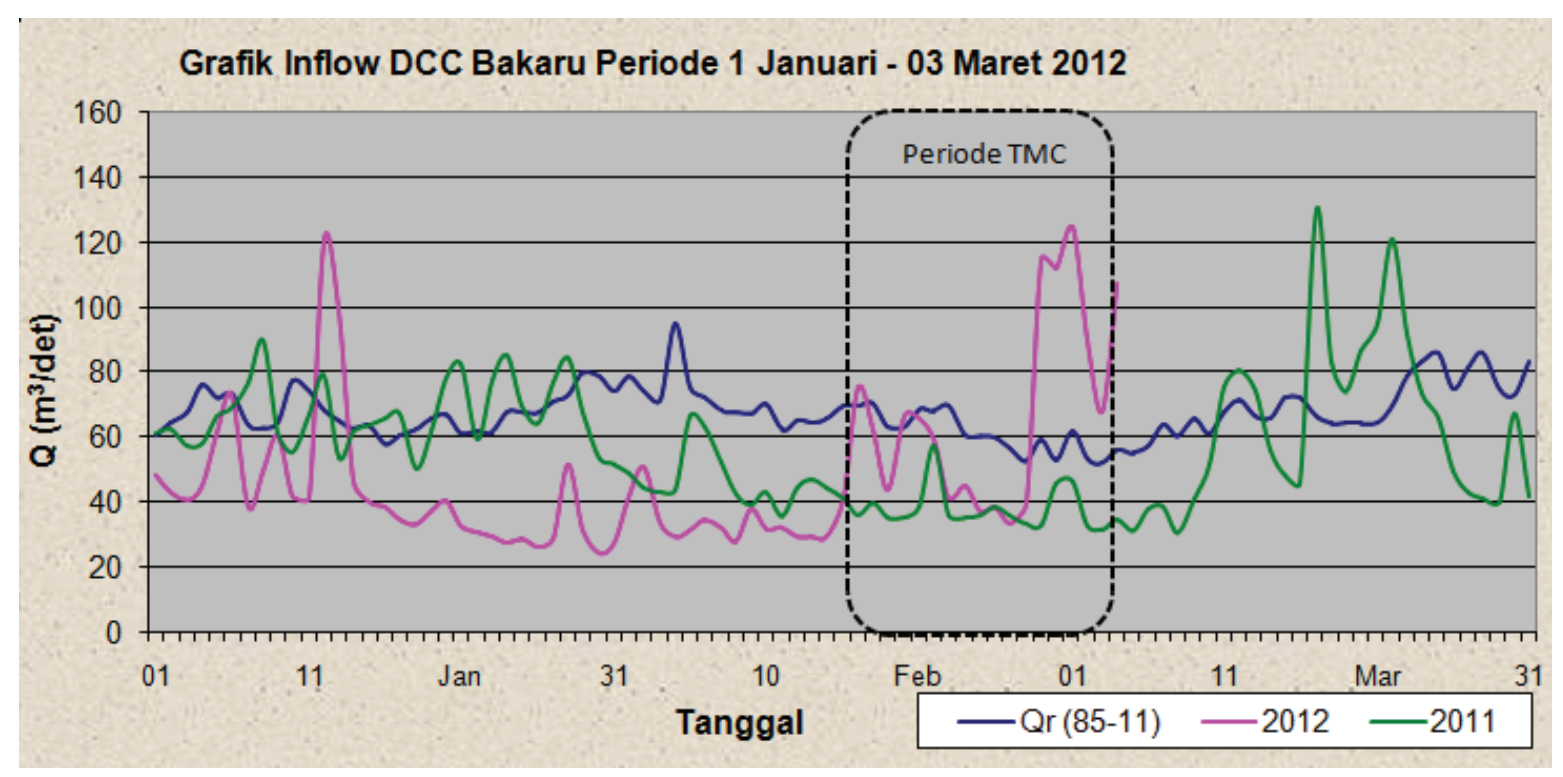

Gambar 12. Kondisi inflow di Bendung Bakaru selama periode Kegiatan TMC dibandingkan kondisi dalam periode yang sama pada tahun 2011 dan historisnya (Qr) 


\section{DAFTAR PUSTAKA}

Climate Prediction Center. 2012. ENSO Cycle: Recent Evolution, Current Status and Predictions, edisi Maret 2012.

Matthew C. Wheeler and Harry H. Hendon. 2004:, An All-Season Real-Time Multivariate MJO Index: Development of an Index for Monitoring and Prediction, Monthly Weather Review, 132, 1917-1932.
Salby, M. L., and H. H. Hendon, 1994: Intraseasonal behavior of clouds, temperature, and motion in the Tropics. J. Atmos. Sci.,51, 2207-2224.

UPT Hujan Buatan, 2011 Laporan Kegiatan Penerapan Teknologi Modifikasi Cuaca Untuk Mengatasi Defisit Inflow PLTA Bakaru Tanggal 15 Februari sd. 03 Maret 2012 (Tahap II), Jakarta, 2009. 